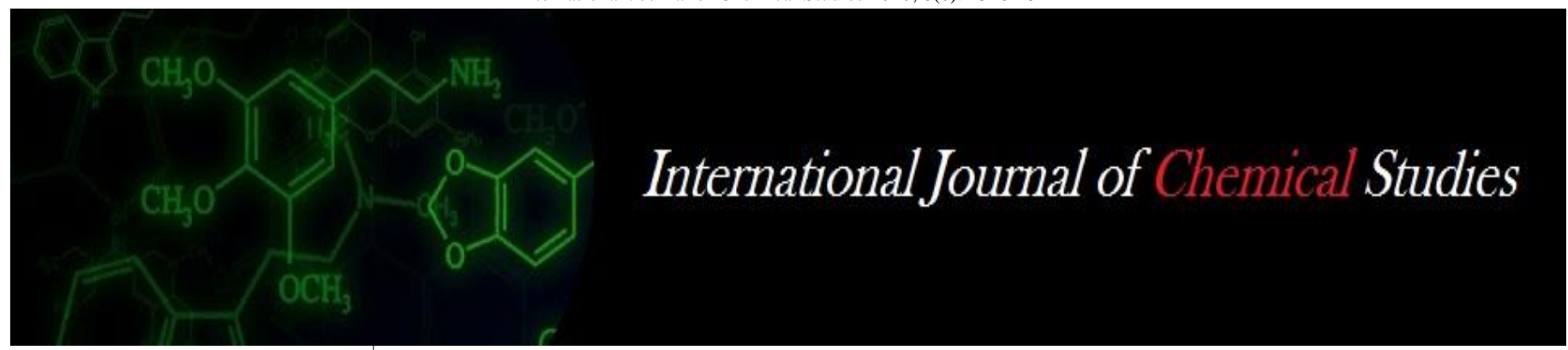

P-ISSN: 2349-8528

E-ISSN: 2321-4902

www.chemijournal.com

IJCS 2020; 8(6): 2518-2521

(C) 2020 IJCS

Received: 06-09-2020

Accepted: 11-10-2020

Vasudev L

Department of Silviculture and Agroforestry, Assistant Professor of Farm Forestry, COH, Hiriyur, Karnataka, India

Raju L Chavan

Senior Scientist \& Head, AICRP on Agroforestry, MARS, UAS,

Dharwad, Karnataka, India

GM Devagiri

Professor and Head, Department of Natural Resource

Management, College of

Forestry, Ponnampet, Kodagu

Dist., UAHS, Shivamogga

Karnataka, India
Corresponding Author:

Vasudev L

Department of Silviculture and Agroforestry, Assistant Professor of Farm Forestry, COH, Hiriyur, Karnataka, India

\section{Effect of soil types and age gradations on growth performance of Melia dubia under central dry zone of Karnataka}

\author{
Vasudev L, Raju L Chavan and GM Devagiri
}

DOI: https://doi.org/10.22271/chemi.2020.v8.i6aj.11149

\begin{abstract}
Melia dubia is a fast growing deciduous tree species has popularity among the farmers and wood based industries to fulfill their growing demands. Several workers have studied on growth performance of different tree species with respect to site factors. A field study was conducted to know the effect of soil types and age gradation on growth of M. dubia in central dry zone of Karnataka during 2018-19. Established plantation in two soil types (Black and red soil) with 2, 4, 6 and 8 year age gradations were selected. Results revealed that, trees grown in black soil recorded maximum height at initial $(7.41 \mathrm{~m})$ and at the end of 12 months $(8.19 \mathrm{~m})$ as compared to red soil at initial $(6.89 \mathrm{~m})$ and after 12 months $(7.65 \mathrm{~m})$. Diameter at breast height $(\mathrm{DBH})$ and crown diameter did not differ significantly with respect to different soil types. Among the age gradation, the maximum height $(10.75 \mathrm{~m}$ and $10.90 \mathrm{~m})$, dbh $(0.218$ and 0.224 $\mathrm{m})$ and crown diameter $(3.44 \mathrm{~m}$ and $4.38 \mathrm{~m})$, basal area $\left(30.981\right.$ and $\left.32.815 \mathrm{~m}^{2} \mathrm{ha}^{-1}\right)$ and wood volume production (200.279 and $\left.241.529 \mathrm{~m}^{3} \mathrm{ha}^{-1}\right)$ at initial and 12 months after start of experiment were recorded in 8 year plantation. Interaction of black soil and 8 year plantation recorded the maximum growth for all the growth parameters and may be recommended for harvest to get maximum returns.
\end{abstract}

Keywords: Melia dubia, wood volume, age gradation, Soil types

\section{Introduction}

Depletion of forest area in the country has badly hit the supply of fibrous raw materials to the industry and hence great importance has been given to raise fast growing species for use as raw material for paper and cellulose industries (Saikia et al., 1997) ${ }^{[3]}$. There is an urgent need to supply the raw materials sustainably for wood based industries through expansion of area under fast growing with short rotation species and enhanced productivity. Under such circumstances Melia dubia has been identified as one of the potential species as a raw material for different wood based industries (Saravanan et al., 2013a) ${ }^{[4]}$. It can grow at the rate of 41.54 $\mathrm{m}^{3}$ ha $^{-1}$ year ${ }^{-1}$ which is higher as compared to Eucalyptus and poplar (Saravanan et al., 2013) [5]. Malabar neem (Melia dubia Cav.), commonly called as Hebbuvu or Dreak or Gora Neem, is a dry deciduous multipurpose tree belongs to the family Meliaceae. It is indigenous to Western Ghats and Himalayas, and grown extensively in Upper Assam, West Bengal, Khasi hills of Orissa, Western Ghats and moist deciduous forests of Kerala up to an altitude of 1500$1800 \mathrm{~m}$ above mean sea level (Ashok et al., 2017) ${ }^{[1]}$. Growth and productivity are one of the factors, which are to be considered while looking for the successful establishment of any plantation. The performance of plantation can be assessed only by calculating the growth and productivity in space and time. The choice of planting density is a primary silvicultural decision in plantation management which considers the tradeoff between individual tree size and total stand production, affecting the type of quality and quantity of products throughout the rotation. Currently there is an increased tendency to grow indigenous tree on a plantation scale, the species like M. dubia is being promoted which is fast growing and can fulfill the economic sustainability of farmers, raw material needs of industries and environment benefits.

\section{Materials and Methods}

\section{Geographical location}

The field experiments were carried out at College of Horticulture, Hiriyur, University of Agricultural and Horticultural Sciences, Shivamogga. 
The experimental sits are situated in Central dry zone (Zone4) of Karnataka and lies between North latitude 13 ${ }^{\circ} 56^{\prime} 57^{\prime \prime}$ and East longitude $76^{\circ} 37^{\prime} 13^{\prime \prime}$ at 606 meters above mean sea level (MSL).

\section{Central dry zone}

This Agro-climatic zone has an area of about 1.98 million ha spread over in 17 taluks of 5 districts of Karnataka state. The elevation ranges from $450 \mathrm{~m}-900 \mathrm{~m}$ above mean sea level, with most parts lies at an elevation of $800 \mathrm{~m}-900 \mathrm{~m}$. The major area of the zone is covered with granite and gneissic landscapes and to a lesser extent with metamorphic landscape of the plateau region.

\section{Climatic conditions}

The study area (Hiriyur) gets benefits from both South- West and North- East monsoon. The mean monthly meteorological data on rainfall, temperature and relative humidity during the period of experimental year (2018-19 and 2019-20) and average annual values for the last 10 years (2008-17) recorded at Zonal Agricultural and Horticultural Research Station, Hiriyur are presented in Table 1 and depicted in Fig. 1 and Fig2.

The average annual rainfall for last 10 years (2008 to 2017) at the study area was $647 \mathrm{~mm}$ and the significant portion of the rainfall received in October $(296.4 \mathrm{~mm})$. During the experimental period, the rainfall received in 2018 (490.4 $\mathrm{mm}$ ) and $2019(788.4 \mathrm{~mm})$ were lower and higher, respectively than the 10 years average annual rainfall. The mean maximum and minimum temperature in the study period was 2018 $\left(32.3^{\circ} \mathrm{C}\right)$ and $2019\left(32.5^{\circ} \mathrm{C}\right)$ as compared to 10 years mean (32.3 and $19.6{ }^{\circ} \mathrm{C}$, respectively). The annual mean relative humidity was $2018(73.9 \%)$ and $2019(74.7 \%)$ recorded was higher than 10 year average humidity $(72.8 \%)$.

\section{Methodology}

Melia dubia plantations established by farmers in different soil types (black soil and red soil) were identified and in each soil type, 4 plantations having age of 2, 4, 6 and 8 year age gradations with $4 \times 3 \mathrm{~m}$ spacing were selected. In each selected plantations, centrally located 20 trees were marked for recording the growth attributes such as total height (m), diameter at breast height $(\mathrm{cm})$ and canopy diameter $(\mathrm{m})$. The basal area per tree $\left(\mathrm{m}^{2}\right.$ tree $\left.\mathrm{e}^{-1}\right)$ and per hectare $\left(\mathrm{m}^{2} \mathrm{ha}^{-1}\right)$, wood volume production $\left(\mathrm{m}^{3}\right.$ tree $\left.\mathrm{e}^{-1}\right)$ and per hectare $\left(\mathrm{m}^{3} \mathrm{ha}^{-1}\right)$ were calculated for two season (at the time of start of experiment and 12 months after initiation of the experiment) in order to assess the productivity as influenced by the soil types.

\section{Results and Discussion}

Results pertaining to growth performance of Melia dubia as influenced by different soil types at different age gradation is presented in Table 1. Results revealed that, significant variation was observed in height growth due to effect of soil types. Trees grown in black soil recorded maximum height at initial $(7.41 \mathrm{~m})$ and at the end of 12 months $(8.19 \mathrm{~m})$ as compared to red soil at initial $(6.89 \mathrm{~m})$ and after 12 months $(7.65 \mathrm{~m})$. However, diameter at breast height $(\mathrm{DBH})$ and crown diameter did not differ significantly with respect to different soil types. The effect of age gradation was significant on height. Among the age gradation, the higher height was recorded in 8 year plantation at initial $(10.75 \mathrm{~m})$ and 12 months $(10.90 \mathrm{~m})$ after start of experiment as compared to rest of age gradation and the lowest was recorded in 2 year plantation at initial $(3.74 \mathrm{~m})$ and 12 months $(4.90 \mathrm{~m})$ after start of experiment.Similar trend was observed for diameter at breast height and crown diameter also.

The crown diameter (m) also showed significant variation due to age gradation. Among the different age gradation, the maximum crown diameter was recorded in 8 year plantation at initial $(3.44 \mathrm{~m})$ and 12 months $(4.38 \mathrm{~m})$ after the start of experiment.

At an initiation of treatments, the diameter at breast height (DBH) showed significant difference due to the interaction of soil types and age gradation. The maximum DBH was recorded in interaction of black soil and 8 year of age gradation at initial $(0.218 \mathrm{~m})$ followed by red soil and 8 year of age at initial observation of experiment $(0.220 \mathrm{~m})$. The lowest DBH was recorded in the interaction of red soil and 2 year age gradation at initiation $(0.111 \mathrm{~m})$ of experiment. Crown diameter did not differed significantly due to soil types and age gradation. The results are in conformity with the findings of Rao et al. (2000) ${ }^{[2]}$ in Leucaena leucocephala, Eucalptus camaldulensis, Acacia albida and Acacia auriculiformis at the age of 9 years Albizia lebbeck (4 m x 4 m) Azadirachta indica (4 m x $4 \mathrm{~m})$, Acacia nilotica (3 m x 3 $\mathrm{m})$ and Tamarindus indica $(4 \mathrm{mx} 4 \mathrm{~m})$ exhibited the height growth of $12.2 \mathrm{~m}, 11.4 \mathrm{~m}, 10.5 \mathrm{~m}$ and $11.2 \mathrm{~m}$ and the dbh of $18.2 \mathrm{~cm}, 13.7 \mathrm{~cm}, 15.2 \mathrm{~cm}$ and $12.7 \mathrm{~cm}$ respectively at the age of 12 years.

Table 1: Growth performance of Melia dubia in different soil types at different age gradation

\begin{tabular}{|c|c|c|c|c|c|c|}
\hline \multirow[b]{2}{*}{ Treatments } & \multicolumn{2}{|c|}{ Height (m) } & \multicolumn{2}{|c|}{ Diameter at breast height (m) } & \multicolumn{2}{|c|}{$\begin{array}{c}\text { Crown } \\
\text { Diameter }(\mathbf{m})\end{array}$} \\
\hline & Initial & 12 MASE & Initial & 12 MASE & Initial & $\begin{array}{c}12 \\
\text { MASE }\end{array}$ \\
\hline \multicolumn{7}{|c|}{ Soil Type } \\
\hline Black & 7.41 & 8.19 & 0.172 & 0.188 & 2.61 & 3.49 \\
\hline Red & 6.89 & 7.65 & 0.169 & 0.190 & 2.51 & 3.39 \\
\hline SEm \pm & 0.11 & 0.10 & 0.002 & 0.003 & 0.09 & 0.08 \\
\hline CD@5\% & 0.32 & 0.31 & NS & NS & NS & $\mathrm{NS}$ \\
\hline \multicolumn{7}{|c|}{ Age Gradation (Years) } \\
\hline 2 & 3.74 & 4.90 & 0.105 & 0.131 & 2.15 & 3.00 \\
\hline 4 & 5.28 & 5.75 & 0.161 & 0.192 & 2.15 & 3.00 \\
\hline 6 & 8.81 & 10.11 & 0.197 & 0.210 & 2.49 & 3.38 \\
\hline 8 & 10.75 & 10.90 & 0.218 & 0.224 & 3.44 & 4.38 \\
\hline SEm \pm & 0.16 & 0.15 & 0.003 & 0.004 & 0.13 & 0.11 \\
\hline CD@5\% & 0.46 & 0.43 & 0.010 & 0.013 & 0.36 & 0.31 \\
\hline \multicolumn{7}{|c|}{ Soil Type $\times$ Age Gradation } \\
\hline Black $\times 2$ & 3.93 & 5.00 & 0.111 & 0.134 & 2.18 & 3.04 \\
\hline Black $\times 4$ & 6.08 & 6.43 & 0.149 & 0.182 & 2.18 & 3.04 \\
\hline
\end{tabular}




\begin{tabular}{|c|c|c|c|c|c|c|}
\hline Black $\times 6$ & 8.80 & 10.16 & 0.206 & 0.217 & 2.34 & 3.23 \\
\hline Black $\times 8$ & 10.83 & 11.15 & 0.218 & 0.220 & 3.74 & 4.65 \\
\hline Red $\times 2$ & 3.56 & 4.81 & 0.100 & 0.128 & 2.12 & 2.96 \\
\hline Red $\times 4$ & 4.48 & 5.08 & 0.156 & 0.201 & 2.12 & 2.96 \\
\hline Red $\times 6$ & 8.83 & 10.05 & 0.188 & 0.204 & 2.65 & 3.54 \\
\hline Red $\times 8$ & 10.55 & 10.70 & 0.216 & 0.228 & 3.14 & 4.10 \\
\hline SEm \pm & 0.22 & 0.21 & 0.005 & 0.006 & 0.177 & 0.150 \\
\hline CD @ 5\% & 0.65 & 0.61 & 0.014 & NS & NS & NS \\
\hline
\end{tabular}

Note: MASE $=$ Months After Start of Experiment; NS = Non-significant

The data pertaining to basal area $\left(\mathrm{m}^{2}\right.$ tree $\mathrm{e}^{-1}$ and $\left.\mathrm{m}^{2} \mathrm{ha}^{-1}\right)$ are presented in Table 2. Results revealed that, the non-significant difference with respect to effect of different soil types. The effect of age gradation on basal area $\left(\mathrm{m}^{2}\right.$ tree $^{-1}$ and $\mathrm{m}^{2}$ ha $\left.{ }^{-1}\right)$ was significantly differed. The maximum basal area per tree was recorded in 8 year plantation at initiation $\left(0.037 \mathrm{~m}^{2}\right.$ tree $\left.^{-1}\right)$ and 12 months $\left(0.039 \mathrm{~m}^{2}\right.$ tree $\left.^{-1}\right)$ while the minimum was recorded in 2 year age plantation at initial $\left(0.009 \mathrm{~m}^{2}\right.$ tree $\left.^{-1}\right)$ and 12 months $\left(0.013 \mathrm{~m}^{2}\right.$ tree $\left.^{-1}\right)$ after start of the experiment. The similar trend was also observed in basal area per hectare.

The basal area $\left(\mathrm{m}^{2} \mathrm{ha}^{-1}\right)$ among the age gradation in 8 year plantation recorded higher basal area per $\mathrm{m}^{2} \mathrm{ha}^{-1}$ at initial and 12 months (30.98 and $32.82 \mathrm{~m}^{2} \mathrm{ha}^{-1}$, respectively) after start of the experiment. The lowest was recorded in 2 year plantation (7.33 and $11.23 \mathrm{~m}^{2} \mathrm{ha}^{-1}$, respectively). Increase in basal area in black soil may be due to increase in soil fertility status.

Table 2: Basal area $\left(\mathrm{m}^{2}\right)$ of Melia dubia in different soil types at different age gradation

\begin{tabular}{|c|c|c|c|c|}
\hline \multirow{2}{*}{${ }_{\text {Treatments }} \begin{array}{c}\text { Parameters/ } \\
\text { Intervals }\end{array}$} & \multicolumn{2}{|c|}{ Basal area $\left(\mathrm{m}^{2}\right.$ tree $\left.^{-1}\right)$} & \multicolumn{2}{|c|}{ Basal area $\left(\mathrm{m}^{2} \mathrm{ha}^{-1}\right)$} \\
\hline & Initial & 12 MASE & Initial & 12 MASE \\
\hline \multicolumn{5}{|c|}{ Soil Type } \\
\hline Black & 0.025 & 0.029 & 20.570 & 24.091 \\
\hline Red & 0.024 & 0.029 & 19.881 & 24.565 \\
\hline SEm \pm & 0.001 & 0.001 & 0.561 & 0.847 \\
\hline CD @ 5\% & NS & NS & $\mathrm{NS}$ & $\mathrm{NS}$ \\
\hline \multicolumn{5}{|c|}{ Age Gradation (Years) } \\
\hline 2 & 0.009 & 0.013 & 7.326 & 11.229 \\
\hline 4 & 0.020 & 0.029 & 15.844 & 24.127 \\
\hline 6 & 0.031 & 0.035 & 25.567 & 29.141 \\
\hline 8 & 0.037 & 0.039 & 30.981 & 32.815 \\
\hline SEm \pm & 0.001 & 0.002 & 0.793 & 1.198 \\
\hline CD @ 5\% & 0.003 & 0.005 & 2.314 & 3.497 \\
\hline \multicolumn{5}{|c|}{ Soil Type $\times$ Age Gradation } \\
\hline Black $\times 2$ & 0.010 & 0.014 & 8.133 & 11.768 \\
\hline Black $\times 4$ & 0.018 & 0.026 & 14.586 & 21.737 \\
\hline Black $\times 6$ & 0.034 & 0.037 & 28.000 & 31.102 \\
\hline Black $\times 8$ & 0.038 & 0.038 & 31.411 & 31.758 \\
\hline Red $\times 2$ & 0.008 & 0.013 & 6.518 & 10.690 \\
\hline Red $\times 4$ & 0.019 & 0.032 & 16.158 & 26.517 \\
\hline $\operatorname{Red} \times 6$ & 0.028 & 0.033 & 23.135 & 27.179 \\
\hline $\operatorname{Red} \times 8$ & 0.036 & 0.041 & 30.400 & 33.873 \\
\hline SEm \pm & 0.002 & 0.003 & 1.121 & 1.694 \\
\hline CD@ @ $5 \%$ & NS & NS & 3.272 & NS \\
\hline
\end{tabular}

Note: MASE = Months after Start of Experiment; NS = Non-significant

The effect of soil type and age gradation on wood volume production per tree and per hectare is presented in Table 3. Perusal of results revealed that, there was significant difference in wood volume production per tree at initiation of experiment due to effect of different soil type. Higher volume per tree was recorded in black soil $\left(0.128 \mathrm{~m}^{3}\right.$ tree $\left.^{-1}\right)$ as compared to red soil $\left(0.115 \mathrm{~m}^{3} \mathrm{ha}^{-1}\right)$ at initiation of start of the experiment.

The effect of soil types showed significant difference in volume per tree and per hectare due to age gradation. Significantly higher volume per tree was recorded in 8 year plantation at initial $\left(0.240 \mathrm{~m}^{3}\right.$ tree $\left.^{-1}\right)$ and 12 months $\left(0.258 \mathrm{~m}^{3}\right.$ tree $\left.^{-1}\right)$ after start of the experiment. Whereas, lowest volume was recorded in 2 year age plantation at initial $\left(0.020 \mathrm{~m}^{3}\right.$ tree $\left.{ }^{1}\right)$ and 12 months $\left(0.040 \mathrm{~m}^{3}\right.$ tree $\left.^{-1}\right)$ after start of the experiment.

Similarly, significantly higher wood volume production per hectare $\left(\mathrm{m}^{3} \mathrm{ha}^{-1}\right)$ was recorded in 8 year plantation at initial (200.279 $\left.\mathrm{m}^{3} \mathrm{ha}^{-1}\right)$ and 12 months (214.529 $\left.\mathrm{m}^{3} \mathrm{ha}^{-1}\right)$ as compare to 2 year plantation at initial $\left(16.630 \mathrm{~m}^{3} \mathrm{ha}^{-1}\right)$ and 12 months $\left(33.080 \mathrm{~m}^{3} \mathrm{ha}^{-1}\right)$ after start of the experiment. Increase in basal area in black soil may be due to increase in soil fertility status. The findings are in conformity with the findings of Rao et al. (2000) ${ }^{[2]}$ in Leucaena leucocephala, Eucalptus camaldulensis, Acacia albida and Acacia auriculiformis at the age of 9 years Albizia lebbeck (4 m x 4 m) Azadirachta indica (4 m x $4 \mathrm{~m})$, Acacia nilotica (3 m x 3 $\mathrm{m})$ and Tamarindus indica (4 $\mathrm{mx} 4 \mathrm{~m}$ ) exhibited the height growth and the dbh at the age of 12 years. 
Table 3: Wood volume $\left(\mathrm{m}^{3}\right.$ tree ${ }^{-1}$ and $\left.\mathrm{m}^{3} \mathrm{ha}^{-1}\right)$ production in Melia dubia in different soil types at different age gradation

\begin{tabular}{|c|c|c|c|c|}
\hline \multirow{2}{*}{\begin{tabular}{|ll} 
& $\begin{array}{l}\text { Parameters } \\
\text { /Intervals }\end{array}$ \\
Treatments &
\end{tabular}} & \multicolumn{2}{|c|}{ Volume $\left(\mathrm{m}^{3}\right.$ tree $\left.^{-1}\right)$} & \multicolumn{2}{|c|}{ Volume $\left(\mathrm{m}^{3} \mathrm{ha}^{-1}\right)$} \\
\hline & Initial & 12 MASE & Initial & 12 MASE \\
\hline \multicolumn{5}{|c|}{ Soil Type } \\
\hline Black & 0.128 & 0.156 & 106.516 & 130.142 \\
\hline Red & 0.115 & 0.148 & 96.073 & 122.885 \\
\hline SEm \pm & 0.005 & 0.006 & 3.878 & 4.953 \\
\hline CD@ @ $5 \%$ & 0.014 & NS & NS & NS \\
\hline \multicolumn{5}{|c|}{ Age Gradation (Years) } \\
\hline 2 & 0.020 & 0.040 & 16.630 & 33.080 \\
\hline 4 & 0.062 & 0.099 & 51.816 & 82.302 \\
\hline 6 & 0.163 & 0.211 & 135.523 & 176.144 \\
\hline 8 & 0.240 & 0.258 & 200.279 & 214.529 \\
\hline SEm \pm & 0.007 & 0.008 & 5.484 & 7.004 \\
\hline CD@ @ $5 \%$ & 0.019 & 0.025 & 16.006 & 20.445 \\
\hline \multicolumn{5}{|c|}{ Soil Type $\times$ Age Gradation } \\
\hline Black $\times 2$ & 0.023 & 0.042 & 19.134 & 35.310 \\
\hline Black $\times 4$ & 0.064 & 0.101 & 53.154 & 83.819 \\
\hline Black $\times 6$ & 0.179 & 0.227 & 148.697 & 188.762 \\
\hline Black $\times 8$ & 0.246 & 0.255 & 205.080 & 212.676 \\
\hline Red $\times 2$ & 0.017 & 0.037 & 14.127 & 30.849 \\
\hline $\operatorname{Red} \times 4$ & 0.054 & 0.097 & 52.330 & 80.785 \\
\hline Red $\times 6$ & 0.147 & 0.196 & 122.349 & 163.525 \\
\hline Red $\times 8$ & 0.235 & 0.260 & 195.478 & 216.381 \\
\hline SEm \pm & 0.009 & 0.012 & 7.755 & 9.906 \\
\hline CD@ @ & $\mathrm{NS}$ & NS & $\mathrm{NS}$ & NS \\
\hline
\end{tabular}

Note: MASE $=$ Months after Start of Experiment; NS = Non-significant

\section{Conclusion}

Trees grown under black soil has recorded higher values for all the growth parameters indicates that the adoptability of species to the black soil. As age increases the growth of tree attributes were recorded higher in 8 year old plantation and it may be harvested at 8 year of age for maximum returns.

\section{Reference}

1. Ashok K, Savita, Priyanka S, Shruti S, Shivani D, Anchal $\mathrm{R}$, et al. Development of High Yielding Varieties of Melia dubia Cav. (Syn. M. composita Benth.). Ind. Forester 2017;143(11):1203-1206.

2. Rao Joseph LG, Sreemannarayana B. Growth and biomass production of some important multipurpose tree species of Rainfed sandy loam soils. Indi. For 2000;126(97):772-781.

3. Saikia SN, Goswami T, Ali F. Evaluation of pulp wood and paper making characteristics of certain fast growing plants. Wood Sci. Tech 1997;31:461-475.

4. Saravanan V, Parthiban KT, Kumar P, Marimuthu P. Wood characterization studies on Melia dubiaCav. For pulp and paper industry at different age gradation. Res. J. Recent. Sci 2013a;2(ISC-2012) 183-188.

5. Saravanan V, Parthiban KT, Kumar P, Marimuthu P. Evaluation of fuel wood properties of Melia dubiaat different age gradation. Res. J. Agric. For. Sci 2013b;1(6):8-12.

6. Saravanan V, Parthiban KT, Kumar P, Marimuthu P. Radial variations in anatomical properties of Melia dubiaC av. at five different ages. Academic J 2013c;8(45):2208-2217. 